\title{
MACROCLINIUM CHASEI (ORCHIDACEAE, ONCIDIINAE): A NEW RECORD FOR BRAZIL
}

\author{
Mathias E. Engels ${ }^{1,3}$ \& Lilien C. Ferneda Rocha ${ }^{2}$ \\ ${ }^{1}$ Assessoria Técnica Ambiental Ltda., Rua Marechal José Bernardino Bormann, 821, Batel, \\ Curitiba, Paraná, Brazil, 80730-350 \\ ${ }^{2}$ Juris Ambientis Consultores S S Ltda., Curitiba, Brazil \\ ${ }^{3}$ Author for correspondence: mathiasengels@hotmail.com
}

\begin{abstract}
We present a new record for Brazil, Macroclinium chasei, until now known only from Bolivia and Peru. A description, illustration and photographs are presented, together with data of geographic distribution, and taxonomical and ecological comments.

Resumo. É apresentado o registro de Macroclinium chasei para o Brasil, conhecida até o momento apenas para a Bolívia e Perú. São fornecidas a descrição, ilustração, prancha fotográfica, além de dados de distribuição geográfica, comentários taxonômicos e ecológicos da espécie.
\end{abstract}

Key words / Palavras chave: Amazon, Amazônia, Macroclinium, Mato Grosso, Oncidiinae, Rio Teles Pires

Introdution. The neotropical genus Macroclinium Barb.Rodr. is constituted by 44 species (Govaerts 2016), found from Mexico to Bolivia and Brazil (Pupulin 1997). Six species had been previously recorded from Brazil: Macroclinium brasiliense (Pabst) Dodson, M. mirabile (C.Schweinf.) Dodson, M. paraense Campacci \& da Silva, M. roseum Barb. Rodr., M. saraca-taquerense Campacci \& da Siva, and M. wullschlaegelianum (Focke) Dodson. The species are distributed in the states of Amazonas, Goiás, Maranhão, Pará, Rio de Janeiro, Rondônia, Roraima, Tocantins and in Distrito Federal (BFG 2015, Campacci et al. 2015).

During the flora rescue at the Hydroeletric Power Plant of Colíder (Mato Grosso State), material of Macroclinium chasei Dodson \& Benn. was collected, corresponding to a new record for Brazil. The species is here presented with a description, illustration, photographs, as well as taxonomical and ecological comments.

\section{TAXONOMIC TREATMENT}

Macroclinium chasei Dodson \& D.E.Benn., Icon. P1. Trop., ser. 2, 1: t. 98 (1989).

TYPE: Peru. Huanuco: Leôncio Prado, 5-7 Km towards La Divisoria from Tingo Maria, $850 \mathrm{~m}$, 20.VII.1987, L. Moore ex D. Bennett \& M. Chase 4092 (holotype MO, illustration!).

Epiphytic herbs. Roots ca. $0.5 \mathrm{~mm}$ thick, terete, whitish. Stem compact, pseudobulbs absent. Leaves alternate and imbricate, $4-6$ by sympodium, $0.7-1.4$ $\times 0.4-0.5 \mathrm{~cm}$, laterally compressed, falcate, slightly fleshy, apex acute to obtuse, green, with reticulate, brownish and thick ribs. Inflorescence axillar, biflowered, at beginning simple, becoming composed with the production of new secundary inflorescences; main peduncle $15-33 \mathrm{~mm}$ long, $0.25 \mathrm{~mm}$ thick, terete, brown to greenish; secundary peduncle $2-3 \mathrm{~mm}$ long, $0.25 \mathrm{~mm}$ thick, terete, brown to greenish. Flowers resupinates. Ovary and pedicel ca. $4 \mathrm{~mm}$ long, 0.3 $\mathrm{mm}$ in diameter, terete, pale green. Dorsal sepal ca. $4 \times 2 \mathrm{~mm}$, elliptic to elliptic-oblanceolate, obtuse to acute, white. Lateral sepals ca. $5.0 \times 2.0-2.5 \mathrm{~mm}$, lanceolate-ovate, obtuse, white. Petals ca. $4 \times 1 \mathrm{~mm}$, narrowly elliptic, acute, white with purple-pink dots. Lip 5.0-6.0 × 1.5-2.0 mm, unguiculate, white to white slightly pink; claw adaxially sub-canaliculate; blade elliptic to elliptic-oblanceolate, acute to obtuse, the margin sometimes slightly ondulate. Column ca. $1.5 \mathrm{~mm}$ long, clinandrium minutely denticulate, 
white with base purple-pink. Anther ca. $0.6 \mathrm{~mm}$ long, dorsifixed, subovate, with two globoses protuberances at the base, these with inconspicuously alveolate surface, apex minutely denticulate, white with base purple-pink. Pollinia 2, ca. $0.3 \mathrm{~mm}$, ovate, laterally flattened, yellow; stipe ca. $1 \mathrm{~mm}$ long, subspathulate, translucid-white; viscidium ca. $0.1 \mathrm{~mm}$ long, rounded, white-brownish. Fruits and seeds not seen.

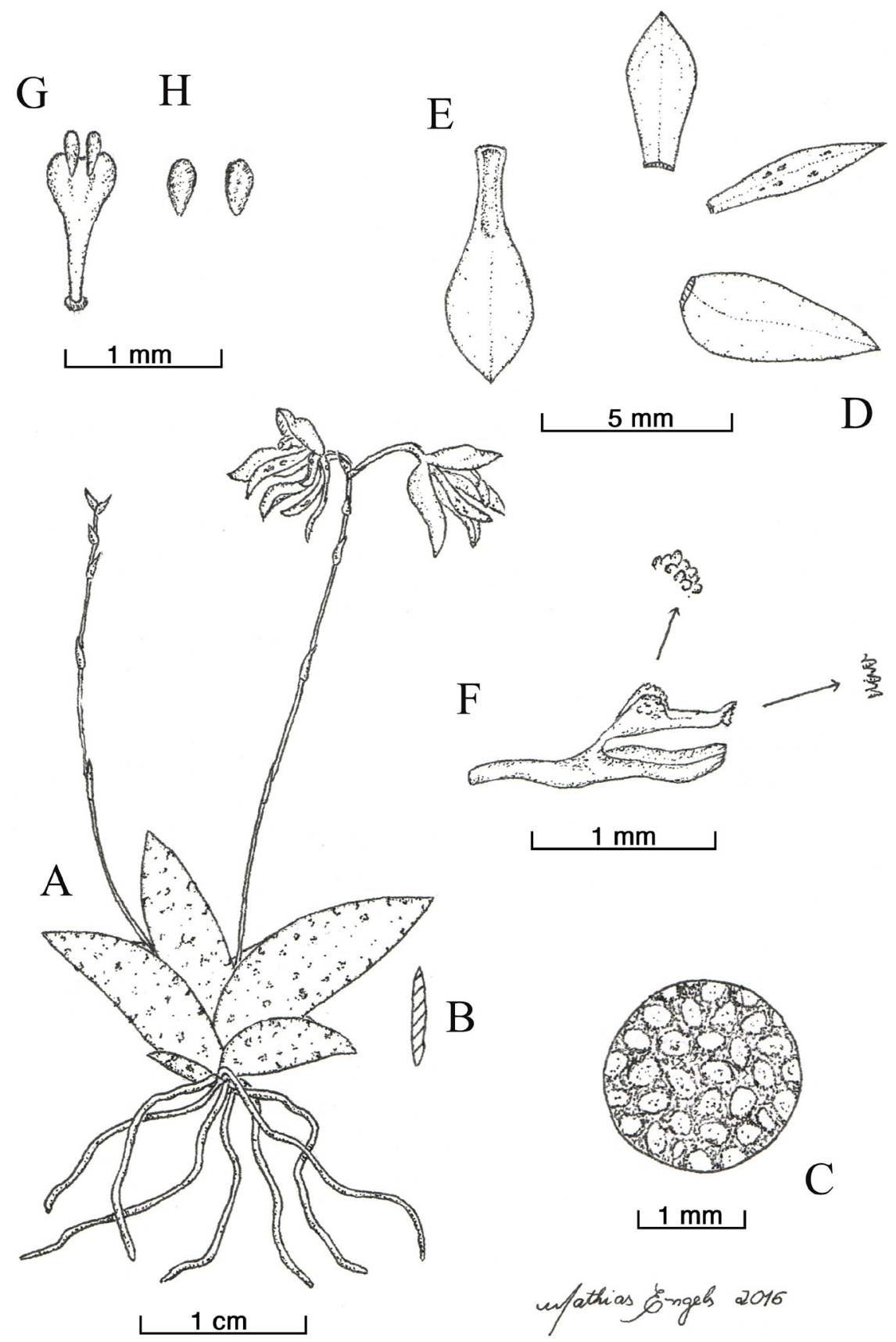

FiguRE 1. Macroclinium chasei. A. Habit. B. Section of leaf. C. Detail of texture of the leaf. D. Perianth flattened. E. Lip flattened. F. Column with anther. G. Pollinarium. H. Pollinia in lateral view. Illustration by M.E.Engels based on Engels \& Bezerra 4773, MBM. 


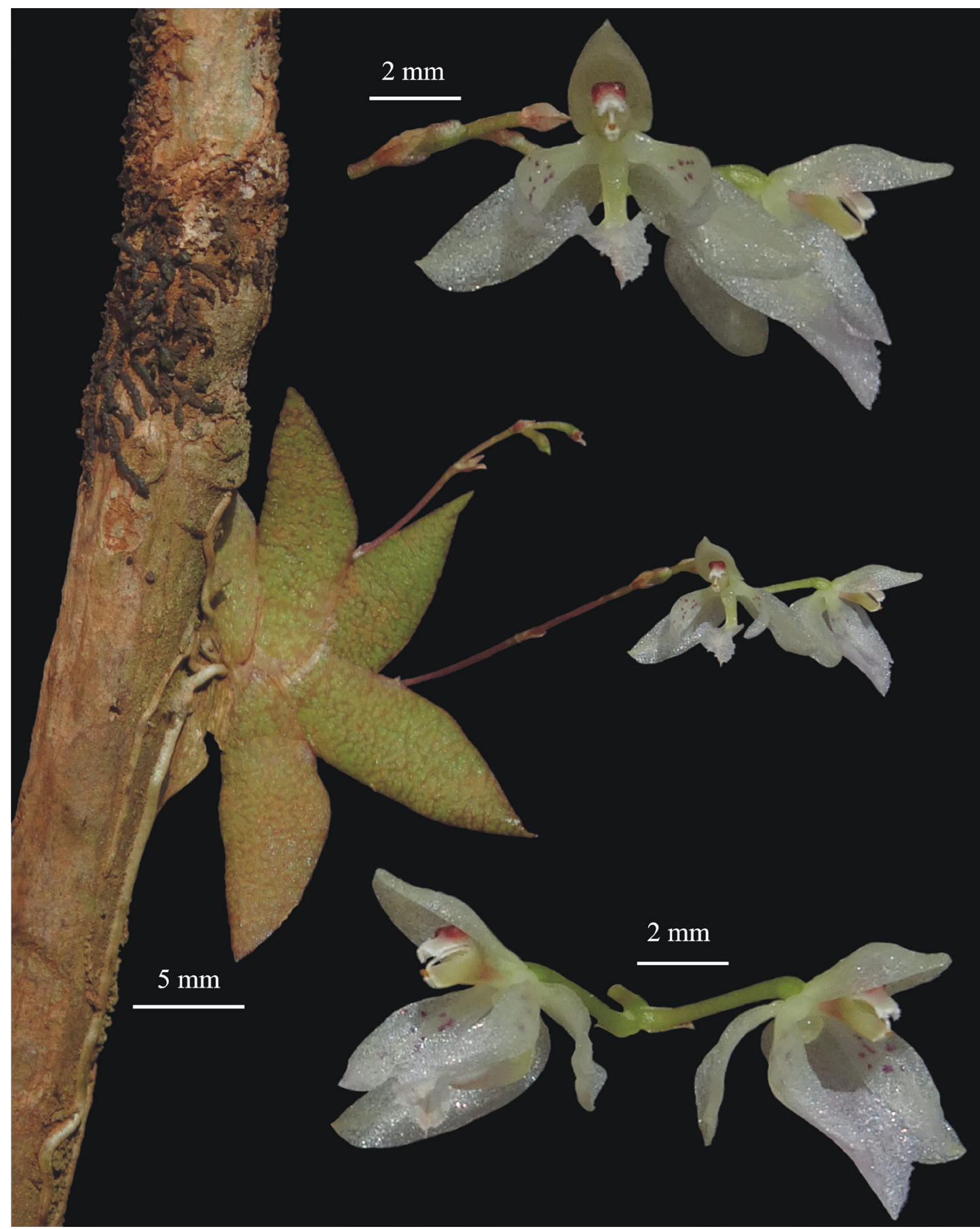

Figure 2. Macroclinium chasei. Habit and flowers (Engels \& Bezerra 4773, MBM). Photographs by M.E. Engels.

ExAminED MATERIAL. Brazil. Mato Grosso: Itaúba, Flora rescue from UHE Colíder, fl., 21 July 2016, M.E. Engels \& A.S. Bezerra 4773 (MBM, RB, TANG spirit collection). Fig. 1-3.
Macroclinium chasei occurs in Bolivia, Peru (Bennet \& Christenson 1994, Pupulin 1997, Carnevali \& Cetzal-Ix 2012, Govaerts 2016) and Brazil, in the Mato Grosso State (Fig. 3). This material correspond 


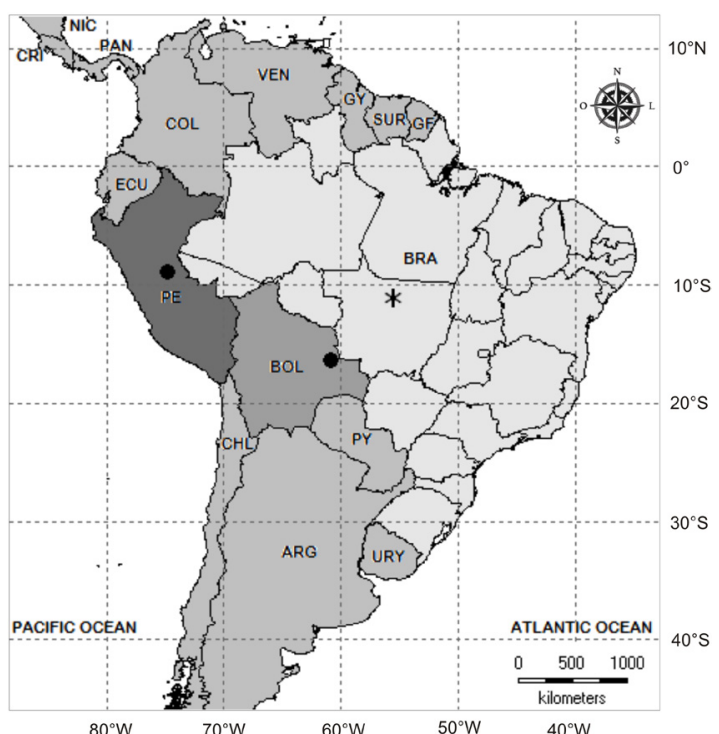

FIGURE 3. Distribution map of Macroclinium chasei. Circle: previous records. Asterisk: current record.

to the first record of the species in Brazil. It was found as an epiphyte of thin branches in the canopy in the paludose forest (Stational Forest Always Green Aluvial) crossed by a tributary stream of the Teles Pires river, in southern Amazonia. Flowering occurs from July to October.

We believe that this species may occur in other areas of the Brazilian southern Amazonian that share the same ecological and phytophysiognomics conditions. According to Miranda and Menini Neto (2010) several orchids are seldom collected because they are rare, occur in places with difficult access (in this case, trees canopy) and are not easily seen during collect expeditions due to their small size. This facts may explain the lack of records of Macroclinium chasei in Brazil until now.

Macroclinium chasei belongs to M. sect. Hirtzae Dodson \& Pupulin, a group characterized by plants without pseudobulbs, non-articulated leaves, biflowered inflorescences, column with thickened apex, dorsal anther, opercule fixed at base of clinandrium, and discoid and flat pollinia (Pupulin 2001). In addition to $M$. chasei, other species belonging to this section are $M$. biflorum Bennet \& Christenson, M. brasiliense, M. dentiferum Thiv, M. hirtzii Dodson, M. mirabile, M. paraense and M. saraca-taquerense. Besides $M$. chasei, other four species of $M$. sect. Hirtzae occur in Brazil: M. brasiliense, M. mirabile, M. paraense and $M$. saraca-taquerense. It differs from these by the entire lip, acute to obtuse apex, without callous and by the apex of the clinandrium and anter minutely denticulate.

The leaf surface of $M$. chasei presents thick and brown reticulations over the green blade (Dodson \& Bennet 1989), a texture that is more evident in individuals living in places with higher exposition to the sun light.

Conservation - Data Deficient (DD): known only from one collect in Brazil, lack of additional individuals from the site and neighboring regions (IUCN 2010).

Acknowledgments. We thank to Companhia Paranaense de Energia (COPEL) for allow and encourage the publication of the data of this work. Consórcio CIA Ambiental and staff are warmly acknowledged. We also thank Carla A. Royer for her help with the bibliography.

\section{LiterATURE CITED}

Bennet, D. B. \& Christenson, E. A. (1994). New species and new combinations in Peruvian Orchidaceae. Brittonia, 46(1), 24-53.

BFG (The Brazil Flora Group). (2015). Growing knowledge: an overview of seed plants diversity in Brazil. Rodriguésia, 66(4),1085-1113.

Campacci, M. A., Bohnke, E., Carr Jr, G. F., Silva, J. B. F. \& Harding, P. A. (2015). Coletânea de orquídeas brasileira - Novas espécies. Coletânea de orquídeas brasileira, $11,405-442$.

Carnevali, G. \& Cetzal-Ix, W. (2012). A new species of Macroclinium (Orchidaceae: Oncidiinae) from Andean Venezuela with brief comments on the biogeography ot the genus. Phytotaxa, 40, 12-20.

Dodson, C. H. \& Bennett, D. E. (1989). Orchids of Peru. Icones Plantarum Tropicarum, series 2, fascicle 1. Plates 0001-0100. St. Louis, Missouri: Missouri Botanical Garden Press.

Govaerts, R. (2016). World Checklist of Selected Plant Families. Facilitated by the Royal Botanic Gardens, Kew. Recovered from www.kew.org/wcsp/monocots [Accessed: 30 September 2016].

IUCN. (2010). Standards and Petitions Working Group. Guidelines for Using the IUCN Red List Categories and Criteria. Versao 8.1. Recovered from iucn.org/webfiles/ doc/SSC/RedList/RedListGuidelines.pdf [Accessed: 30 September 2016].

Miranda, M. R. \& Menini Neto, L. (2010). Redescoberta de 
Centroglossa macroceras Barb. Rodr. e Thysanoglossa jordanensis Porto \& Brade (Orchidaceae), duas microorquídeas consideradas presumivelmente extintas no Estado de São Paulo, Brasil. Hoehnea, 37(2), 403-405.
Pupulin, F. (1997). Una sinossi del genere Macroclinium (Orchidaceae: Oncidiinae). Caesiana, 9, 1-20.

Pupulin, F. (2001). Miscellaneous new taxa in Neotropical Orchidaceae. Selbyana, 22(1), 14-26. 
LANKESTERIANA

LANKESTERIANA 17(3). 2017. (C) Universidad de Costa Rica, 2017. 